\title{
Rectification of description of Notodiaptomus spinuliferus, Dussart and Matsumura-Tundisi, 1986
}

\author{
Matsumura-Tundisi, T.* \\ Instituto Internacional de Ecologia - IEE \\ Rua Bento Carlos 750, CEP 13560-660, São Carlos, SP, Brazil \\ *e-mail: tmt.iie@iie.com.br \\ Received October 18, 2007 - Accepted November 8, 2007 - Distributed August 31, 2008
}

(With 2 figures)

The aim of this note is to rectify the description of Notodiaptomus spinuliferus n.sp. described by Dussart and Matsumura-Tundisi, 1986, from the material collected in Ilha Solteira Reservoir, São Paulo State during the expedition carried out in the 1979 in the project: Typology of reservoirs of São Paulo State (Tundisi, 1981). Dussart and Matsumura-Tundisi, 1986, described a new species of Calanoida from Ilha Solteira Reservoir as Notodiaptomus spinuliferus, However the figures associated were not of the new species but they were of Notodiaptomus deitersi from the material collected in the Pantanal region (MT, Brazil). The original figures of Notodiaptomus spinuliferus were presented in Matsumura-Tundisi, 1986, without however its diagnose description.

Figure 1 refers to drawings of different parts of Notodiaptomus spinuliferus presented in MatsumuraTundisi, 1986, and the microscopic photography of $5^{\text {th }}$ leg of male of the specimen from Rosana Reservori (SP).

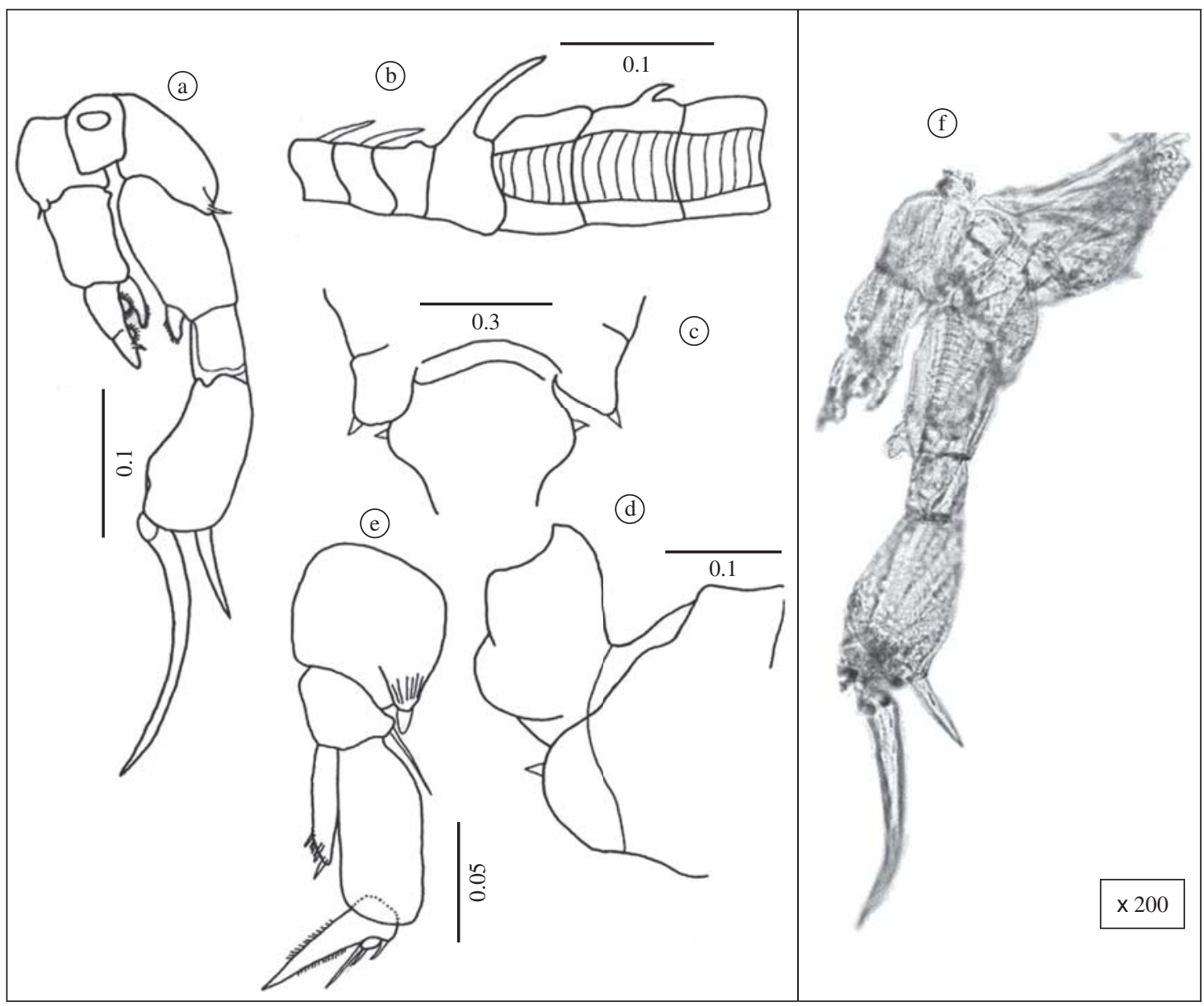

Figure 1. Notodiaptomus spinuliferus. From a-e) drawings of different parts of the specimen from Ilha Solteira reservoir: a) $5^{\text {th }}$ leg of male; b) right antennae of male; c,d) details of last thoracic segment of female; and e) $5^{\text {th }}$ leg of female, in Matsumura-Tundisi, 1986; f) microscopic photography of $5^{\text {th }}$ leg of male from Rosana Reservoir specimen taken by the author. 


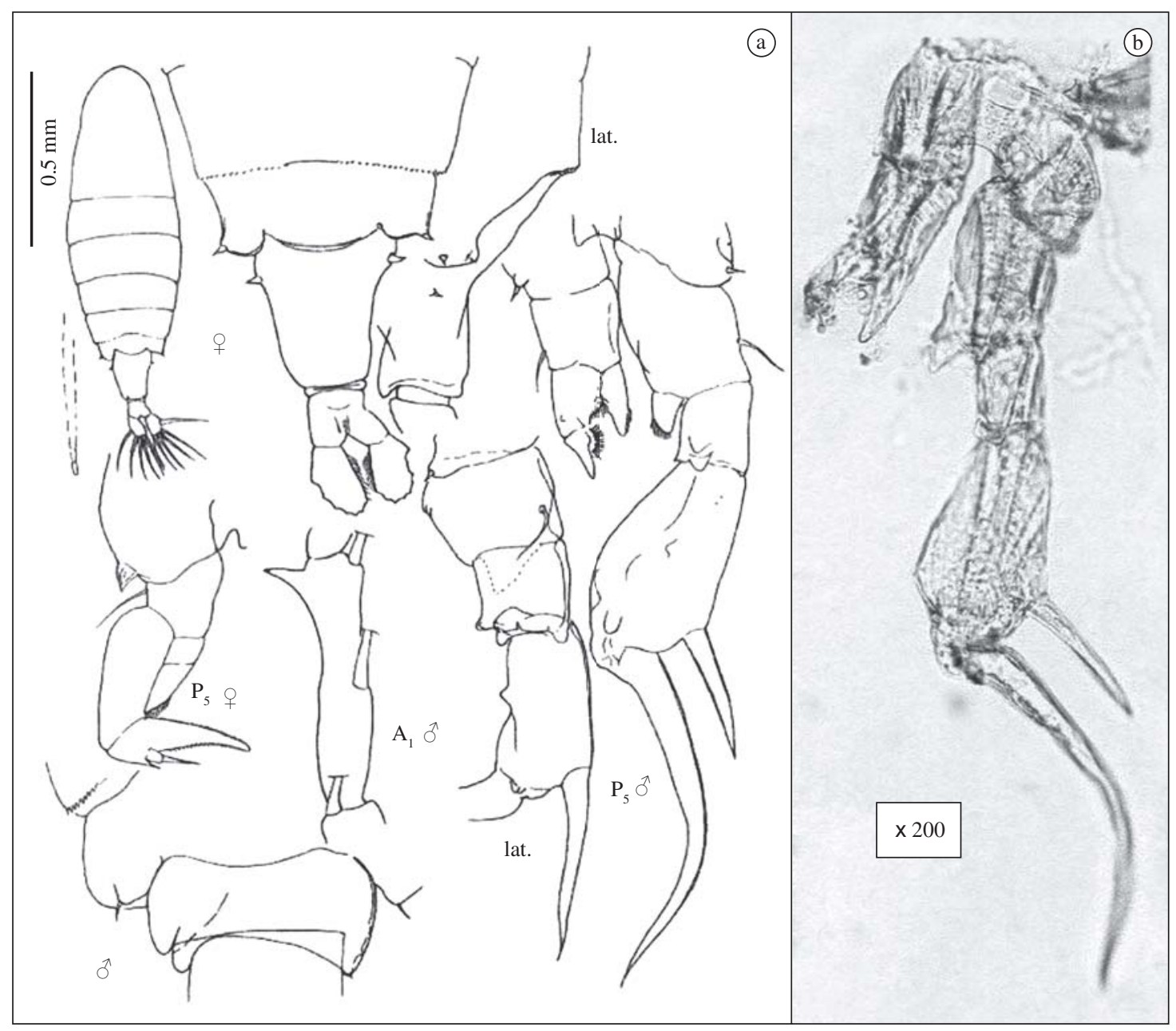

Figure 2. Notodiaptomus deitersi. a) drawings of the specimen from the Pantanal region (MT), from Dusssart and Matsumura-Tundisi, 1986; and b) microscopic photograph of $5^{\text {th }}$ leg of male from Barra Reservoir specimen taken by the author.

Figure 2 refers to the drawings of Notodiaptomus deitersi presented in Dussart and Matsumura-Tundisi, 1986 as Notodiaptomus spinuliferus (a) and the microscopic photography of $5^{\text {th }}$ leg of male of Notodiaptomus deitersi from Barra Reservoir (SP)

In further limnological studies carried out between 1999 to 2003 in 220 water bodies located in 22 hydrographic basin of São Paulo State (BIOTA/ FAPESP Project, 2003) it was observed the occurrence of Notodiaptomus spinuliferus in several reservoirs of Paranapanema basin (Represas: Rosana, Taquaruçu, Capivara, Jurumirim, Salto Grande). Notodiaptomus deitersi was registered in Paiva Castro Reservoir (Higher Tietê River basin), Ibitinga Reservoir (Tietê/ Jacaré basin), Porto Raso Reservoir and Barra Reservoir (Ribeira do Iguape basin).

\section{References}

DUSSART, BH. and MATSUMURA-TUNDISI, T., 1986. Nouvelles espècies de Calanoïdes du Brèsil. Rev. Brasil. Biol. $=$ Braz. J. Biol., vol. 46, no. 1, p. 249-255.

MATSUMURA-TUNDISI, T., 1986. Latitudinal distribution of Calanoida copepods in freshwater aquatic systems of Brazil. Rev. Brasil. Biol. = Braz. J. Biol., vol. 46, no. 3, p. 527-553.

TUNDISI, JG., 1981. Typology of reservoirs in southern Brazil. Verh. Internat. Verein. Limnol., vol. 21, p. 1031-1039.

BIOTA/FAPESP PROJECT, 2003. Biodiversity of freshwater zooplankton of São Paulo Satate and its relation to the preserved and non preserved areas. (Reports: 1,2,3,4,5). 